\title{
Pressure from Without, Subversion from Within: The Two-Pronged German Employer Offensive ${ }^{1}$
}

\author{
by \\ Daniel Kinderman
}

Daniel Kinderman is a PhD Student at the Department of Government, White Hall, Cornell University. He can be reached at: dpk24@cornell.edu

\footnotetext{
${ }^{1}$ The author gratefully acknowledges support from the German Academic Exchange Service (DAAD), the Province of Ontario (Canada), and the Canadian Centre for German and European Studies (CCGES), which made this research possible. He would also like to thank Kurt Hübner, Peter Katzenstein and Jonas Pontusson. Special thanks goes to Christopher Way, whose numerous and detailed comments and suggestions have benefited this paper tremendously, and Claude Desmarais, who edited the text for the CCGES. None of these people are in any way responsible for the deficiencies that remain.
} 
Copyright $(\odot$ by the CCGES/CCEAE 2003.

All rights reserved.

Working Paper Series Number 6.

"Pressure from Without, Subversion from Within:

The Two-Pronged German Employer Offensive." Daniel Kinderman

The views expressed in the Working Papers are those of the authors and do not necessarily reflect those of The Canadian Centre for German and European Studies/Le Centre canadien d'études allemandes et européennes.

CCGES/CCEAE welcomes offers for publications. Please send your papers to the CCGES at York University.

Les opinions exprimées dans les Notes de Recherche sont celles de l'auteur. Elles ne reflètent pas nécessairement le point de vue du CCEAE.

CCGES/CCEAE accepte volontiers des propositions d'articles. Faites parvenir votre article au Centre:

CCGES

Prof. Kurt Huebner 230 York Lanes

York University 4700 Keele Street Toronto, ON, Canada M3J 1P3
CCEAE

Prof. Laurent McFalls

Université de Montréal

Pavillon 3744, rue Jean- Brillant, bureau 525 Montréal, Qc, Canada

H3T 1P1 


\section{Abstract/Resumé/Zusammenfassung}

The conventional wisdom, which has received its most recent formulation in the "Varieties of Capitalism" literature, views Germany as a paragon of institutional continuity and stability. Scholars of German political economy have focused on continuity of structure and, having established this, have inferred continuity of content. By contrast, I argue that German employers are attempting to subvert existing institutions from without (politically) and from within (in the industrial relations realm). Focusing on continuity in formal structures is misleading because this blinds analysts to important changes in content/practices; we this most clearly in new management strategies which alter the very essence of workplace labor relations.

This paper addresses the qualitative shift in the German social market economy, thus far largely neglected by English language literature. It does so by interrogating employer preferences and new management techniques in the German political economy. Claims of structural conservatism in German employer preferences are debunked through a detailed look at the content of changing management styles, which exercise paradigmatic influence as filters between international competitive pressures and firms' individual rationalization strategies. In the process, attention is shifted away from "Varieties of Capitalism" literature's focus on levels of bargaining. Thus, this paper also demonstrates how the continued existence of traditional institutions of the German model masks discontinuities which point to a qualitative convergence between German and liberal market counterparts. After discussing employer preference, the social construction of economic reform and the question of employer unity, this paper concludes by addressing the qualitative shift caused by new management strategies.

Ce travail analyse le changement qualitatif survenu dans le sozialer Marktwirtschaft allemand en examinant les préférences patronales et les nouvelles méthodes de gestion dans l'économie politique allemande; thème négligé par la plupart des scientifiques anglophones. La thèse selon laquelle les préferences des employeurs allemands vont vers une structure conservatrice est contredite grâce à un examen minutieux du contenu des changements qui se sont produits dans le style de gestion. Ces changements ont une influence paradigmatique, en tant que filtres entre les tensions de la compétition internationale et les stratégies de rationalisation propres à chaque entreprise individuelle. Cette démarche déplace l'attention qui, dans la littérature des "variétés du capitalisme," se portait sur les niveaux de négociation. Par conséquent, ce travail démontre aussi que la continuité des institutions traditionelles du modèle allemand cache des discontinuités. Ces mêmes discontinuités révèlent une convergence qualitative entre le modèle allemand et ses contreparties des économies libérales. Après une discussion sur les préférences patronales, la construction sociale de la réforme économique et la 
question de l'unité patronale, ce travail se termine par une analyse du déplacement qualitatif entraîné par les nouvelles stratégies de gestion.

Diese Arbeit beschäftigt sich mit dem qualitativen Wandel in der deutschen sozialen Marktwirtschaft durch eine Analyse der Arbeitgeberpräferenzen und der neuen Führungsmethoden der deutschen Wirtschaft; ein Thema, das die englische Literatur zum größten Teil unbeachtet lässt. Entgegen der These vom strukturellen Konservatismus in deutschen Arbeitgeberpräferenzen ergibt ein eingehender Blick auf den Inhalt der wechselnden Management-Arten mit ihrer paradigmatischen Funktion als Filter zwischen dem internationalen Wettbewerbsdruck und den Rationalisierungsstrategien einzelner Firmen ein andres Bild. Damit wird von der in der "Varieties of Capitalism" Forschung üblichen Beschäftigung mit den Verhandlungsniveaus abgesehen. Aus diesem veränderten Blickwinkel erkennt man, dass das Weiterbestehen des deutschen Modells mit seiner traditionellen Ausrichtung Brüche verdeckt, die auf eine qualitative Annäherung zwischen deutschen und liberalen Marktwirtschaften hinweisen. Nach der Behandlung der Arbeitergeberpräferenzen, der sozialen Konstruktion der ökonomischen Reformen sowie der Frage der Arbeitergebereinheit schließt diese Arbeit mit einem Hinweis auf die durch neue Führungsstrategien bedingten qualitativen Veränderungen in der deutschen Wirtschaft. 


\section{Contents}

I. Introduction

Pressure from Without: The Political Realm

II. Employer Preferences and Economic Reforms

III. The Social Construction of Economic Reform

IV. The 'New' Social Market Economy

V. A Paralyzing Employer Disunity?

VI. Changing the Structure Through Content: The Paradigm Shift

VII. Conclusion

VIII. Appendix

IX. Bibliography 


\section{Introduction. Pressure From Without: The Political Realm}

It is difficult to generalize about the recent dynamics of the German political economy; the current conjuncture is fundamentally ambiguous. Even as shareholder value is steadily gaining in influence, ${ }^{2}$ 'traditional' institutions such as works councils and sectoral collective bargaining persist. Emphasizing this continuity, the conventional wisdom sees Germany as a paragon of institutional continuity and stability in the midst of stormy seas. Kurt Hübner concludes his study of globalization's impact on Germany by noting that "the entire organizational structure of the German economy generates an inward-oriented gravitation." ${ }^{3}$ In her monograph on German labor relations published in the early 1990s, Kathleen Thelen remarks that "in the end, not institutional rigidity, but resiliency and flexibility, is what accounts for the continued stability of negotiated adjustment in Germany." ${ }^{4}$ Surveying the 1980s, Peter Katzenstein finds that "experimentation and change within a stable institutional framework" captures the central dynamic of German industry and politics. ${ }^{5}$

The recent "Varieties of Capitalism" literature follows a similar tack. Peter Hall and David Soskice predict "a bifurcated response marked by widespread deregulation in liberal market economies and limited movement in coordinated market economies." According to Stewart Wood, "German employers since the

\footnotetext{
${ }^{2}$ See especially the studies by the Max-Planck Institute for the Study of Societies in Cologne, for example, Martin Höpner, "Corporate Governance in Transition: Ten Empirical Findings on Shareholder Value and Industrial Relations in Germany." Cologne: MPIfG Discussion Paper 01/5, 2001.

${ }^{3}$ Kurt Hübner, Der Globaliserungskomplex. Berlin: Edition Sigma, 1998, p. 246.

${ }^{4}$ Kathleen Thelen, Union of Parts. Ithaca: Cornell University Press, 1991, p. 230.

${ }^{5}$ Peter J. Katzenstein, "Stability and Change in the Emerging Third Republic" Peter J. Katzenstein (ed.) Industry and Politics in West Germany Ithaca: Cornell University Press, 1989, p. 308.

${ }^{6}$ Peter A. Hall and David Soskice, "Introduction," Peter Hall and David Soskice, Varieties of Capitalism New York: Oxford University Press, 2001, p. 58.
} 
early 1980 s have repeatedly failed to bite when offered the carrot of deregulation."7 The effect of efforts "to encourage more flexible forms of employment $[\ldots]$ has been small because of low employer interest." ${ }^{8}$ According to these scholars, the reason for Germany's "limited movement" is that employers' competitive strategies depend upon non-market coordination and regulation. Their basic point seems to be this: There is a lot for firms to like about the existing system. Employers shouldn't be unhappy.

There is much to recommend the conventional wisdom. But it also has difficulty accounting for an increasing number of 'anomalies' which are quietly transforming Germany's institutional landscape. Because many of the analytical tools utilized by scholars are derived from the old paradigm, they tend to overlook growing evidence of the new, emerging one. In this paper, I argue that the conventional wisdom overlooks important aspects of change in the German political economy. Scholars of German political economy have focused on continuity of structure and, having established this, have inferred continuity of content. By contrast, I argue that by changing the content, German employers are in fact changing the structure of the German model. Focusing on continuity in formal structures is misleading because this blinds analysts to importance changes in content/practices. We see this most clearly in new management strategies which alter the very essence of workplace labor relations.

In this paper, I argue that German employers are challenging the existing system on two fronts: By attacking the legitimacy of existing institutions in the

\footnotetext{
${ }^{7}$ Stewart Wood, "Labor Market Regimes under Threat? Sources of Continuity in Germany, Britain, and Sweden" Paul Pierson (ed.) The New Politics of the Welfare State New York: Oxford University Press, 2001, p. 408.
} 
political realm, and by introducing radical new management strategies in the industrial relations realm. As a consequence of these initiatives, a growing number of German employers are unfettered by apparently constricting institutions, such as sectoral collective bargaining and works councils. Employers circumvent these constraints through the introduction of new management and production organization strategies.

In general, these strategies are Janus-faced. On one hand they allow employees increased autonomy and freedom within their work. On the other hand they have a tendency to lengthen employees' working hours without commensurate pay; and in their most radical form, they constitute a de facto decentralization of the wage bargaining system, down to the level of the individual employee. A recent account of these developments explains that these strategies "fundamentally challenge the German system of industrial relations." Organized labor has responded with a number of promising initiatives, but it has yet to fundamentally challenge this re-commodification of labor.

This paper challenges the 'Varieties of Capitalism' literature on two counts. Firstly, though Peter Hall and David Soskice are to be commended for 'bringing the firm and employer preferences' back on to the centre stage of analysis, the result is if anything too firm-centric. There is a tendency to lose sight of the fact that not institutions per se, but rather the benefits which institutions provided for workers was distinctive of the German model of political economy. These benefits are threatened by German employers' two-pronged offensive.

\footnotetext{
${ }^{8}$ Wood, “Labor Market Regimes under Threat,” p. 380.
} 
Secondly, I take the "Varieties" literature to imply the falsifiable proposition that there's a lot for firms to like about the existing system: Employers wouldn't want to transform it, even if they could. Under conditions of institutional arbitrage and intense competition on global product markets, firms will redouble and reinforce the non-market coordination that is the lifeblood of their comparative advantage. They should be happy campers. A closer look shows that they are not. Although by no means an exhaustive survey, this paper finds ample evidence that German employers are challenging the system from without, and subverting it from within. The argument of this paper about the increasing prevalence of market coordination in workplace labor relations, if correct, could be damaging for Varieties of Capitalism's emphasis on the divergence of Coordinated and Liberal Market Economies.

The first half of this paper addresses the political realm. I begin by looking at the question of German employer preferences and the new social market economy initiative. I use the example of this initiative, a large-scale public relations campaign initiated and funded by German employers, to challenge the claim that German employers are structurally conservative in their outlook and orientation: They really want change. The second half of the paper addresses the industrial relations realm. This section shows that employers are not paralyzed by disunity but rather, are getting much of what they want within existing structures, by subverting them from within through the introduction of new management and production strategies.

\footnotetext{
${ }^{9}$ Thomas Haipeter, Steffen Lehndorff, Gabi Schilling, Dorothea Voss-Dahm and Alexandra Wagner,

"Vertrauensarbeitszeit: Analyse eines Rationalisierungskonzeptes" Leviathan Heft 3, September 2000, p. 380.
} 


\section{Employer Preferences and Economic Reforms}

One of the most striking claims of the Varieties of Capitalism literature is that employer preferences are qualitatively different in Liberal Market Economies (LMEs) and Coordinated Market Economies (CMEs). In LMEs, business will favor liberalization, deregulation, and other measures to bring about 'unfettered' markets, whereas in CMEs employers will be careful not to dismantle structures of non-market coordination which enable them to overcome collective-action problems. The 'Varieties' approach thus purports to explain both the neoliberal radicalism of Thatcher and Reagan in LMEs, as well as the structurally conservative employer preferences in CMEs such as Germany. In this vein, Stewart Wood has argued that:

the greatest constraint on reforms that were designed to advance the interests of firms and managers was provided by employers themselves. [...] German employers since the early 1980s have repeatedly failed to bite when offered the carrot of deregulation ${ }^{10}$

Similarly, Philip Manow has concluded that during the 1990s "the continental welfare states experienced little change [...] since both employers and unions often shared lukewarm support at best for attempts at profound reforms." ${ }^{11}$ According to the Varieties approach, German employers' hesitance to dismantle the institutions of the German model and embark on a more radical path of liberalization/deregulation stems from their continued reliance on these nonmarket coordination structures for their own competitive strategies, and from the

\footnotetext{
${ }^{10}$ Stewart Wood, "Weakening Codetermination? Works Council Reform in West Germany in the 1980s" Berlin: Wissenschaftszentrum Berlin für Sozialforschung Discussion Paper FSI97-302, 1997, p. 26, and "Labor Market Regimes under Threat?," p. 408.
} 
difficulties involved in "articulating a viable alternative within the context of existing structures." ${ }^{\prime 2}$ Such assertions of institutional continuity and structurally conservative employer preferences were well-grounded in the past, but their persistence in the recent literature on Germany presents a misleading picture. ${ }^{13}$ Moreover, the disjuncture between the stated interests of corporate actors in Germany and the deductive-functionalist interests ascribed to them by the "Varieties of Capitalism" literature is striking. According to Hall and Soskice:

[in CMEs] governments should be less sympathetic to deregulation because it threatens the nation's comparative institutional advantages. Although there will be some calls for deregulation even in such settings, the business community is likely to provide less support for it, because many firms draw competitive advantages from systems of relational contracting that depend on the presence of supportive regulatory regimes ${ }^{14}$

But German employers are clearly discontented with the rate of change and the limited extent of deregulation. The Bundesverband der Deutschen

Arbeitgeberverbände (BDA), the organization which houses virtually all of the German employers associations which negotiate with unions, has bluntly stated: "our theme is deregulation." 15 The Bundesverband der Deutschen Industrie (Federation of German Industry, henceforth BDI) is of the view that "moderate reforms in Germany do not go far enough." ${ }^{16}$ More to the point, and this is the main theme of this paper, the traditional institutions of the German model are

\footnotetext{
${ }^{11}$ Philip Manow, "Comparative Institutional Advantages of Welfare State Regimes and New Coalitions in Welfare State Reforms" Paul Pierson (ed.) The New Politics of the Welfare State, p. 161.

${ }^{12}$ See for example Kathleen Thelen, "Why German Employers Cannot Bring themselves to Dismantle the German Model" Torben Iversen, Jonas Pontusson and David Soskice, Unions, Employers, and Central Banks Cambridge: Cambridge University Press, 2000, pp. 138-169.The excerpted passage is from p. 163.

${ }^{13}$ For example Robert Henry Cox, "The Social Construction of an Imperative: Why Welfare Reform Happened in Denmark and the Netherlands but Not in Germany" World Politics, April 2001, pp. 463-498.

${ }^{14}$ Peter A. Hall and David Soskice, "An Introduction to Varieties of Capitalism," Varieties of Capitalism, p. 58.

${ }^{15}$ Interview with Elmar Sulk, public relations officer for the BDA, Berlin, July 23, 2002.

${ }^{16}$ Matthias Krämer, BDI, Berlin, personal communication, September 23, 2002.
} 
increasingly being penetrated and transformed by market forces even as structural reform proceeds at a snail's pace.

\section{The Social Construction of Economic Reform}

One scholar who has recently addressed the social construction of regime change in Germany is Robert Henry Cox. ${ }^{17}$ Cox argues that in Germany "reforms have not taken place [...] because political leaders failed to shape a path for them. [...] The absence of reform in Germany corresponds to the absence of a new consensus that reform is necessary. ${ }^{18}$ This claim is sustainable only if 'consensus' is used in a very strict sense. In fact, Cox has the story backward: It is the reforms that have lagged behind the rhetoric, not vice-versa. I substantiate this claim with three different indicators of employer and public opinion: The political orientation of the media, public opinion surveys, and statements by the protagonists.

The discourse in the major print media and in the public sphere, the first indicator, is strongly pro-reform in orientation. While I cannot make strong claims with a selective sample of the press, there are numerous examples of pro-reform rhetoric, contrary to what Cox's position would lead us to expect. Heiner Ganßmann and Michael Haas remark that "the Kiel approach to economics [the 'Eurosclerosis' economic sickness was first 'sighted' in Kiel] has almost monopolized economics debates and the media." ${ }^{19}$

\footnotetext{
${ }^{17}$ Robert Henry Cox, "The Social Construction of an Imperative: Why Welfare Reform Happened in Denmark and the Netherlands but Not in Germany" World Politics Vol. 53, April 2001, pp. 463-498.

${ }^{18}$ Robert Henry Cox, "The Social Construction of an Imperative," p. 489; p. 493.

${ }^{19}$ Heiner Ganßmann and Michael Haas, "Eurosklerose?" PROKLA Vol. 29, Issue 114, No. 1, pp. 56.
} 
Similar examples abound. In 1996 and 1997, the CDU-governed

provinces of Bavaria and Saxony commissioned a report on the future of work and unemployment in Germany, the Bayerisch-Sächsische Zukunftskommission.

As critical commentators acknowledge, this manifesto really focuses on "neoliberal hegemony in the public discourse about unemployment, the welfare state, and inequality." ${ }^{20} \mathrm{~A}$ more recent public relations initiative is titled "Deutschland packts an." ${ }^{21}$ This campaign has been granted free airtime on television networks and billboards by advertising agencies: The reform message is ubiquitous, although it is veiled behind a rhetoric of 'personal initiative' and 'civic duty' as values necessary to overcome Germany's economic tribulations. ${ }^{22}$

Recent public opinion surveys, the second indicator, purport to show that "trust in the market has grown noticeably;" a relative majority of voters favour an expansion of market mechanisms, more competition, and deregulation (including labor market deregulation) ${ }^{23}$ In one recent survey, respondents favored a shift from welfare state compensation to freer market forces within the amalgam of market and social compensation which makes up the "social market economy."

\footnotetext{
${ }^{20}$ Joachim Bergmann, "Die negative Utopie des Neoliberalismus oder die Rendite muß stimmen” Leviathan. Vol. 26, No. 3, p. 320. See also Claus Offe, Susanne Fuchs, Gert Wagner and Hans-Jürgen Krupp, "Zurck in die Zukunft: Stellungsnahmen zum dritten Bericht der Miegel-Kommission," Blätter für deutsche und internationale Politik, Issue 3, 1998, pp. 295-311, and Rudolf Steinke (ed.) "Die Sackgassen der Zukunftskommission: Streitschrift wider die Kommission für Zukunftsfragen der Freistaaten Bayern und Sachsen” Berlin: Senatsverwaltung für Arbeit, Berufliche Bildung und Frauen, Arbeitsmarktpolitische Schriftenreihe Band 33, 1998.

${ }^{21}$ www.deutschlandpacktsan.de

${ }^{22}$ The campaign's name derives from the 'Adlon' speech given by former German president Roman Herzog. For further information, see www.deutschlandpacktsan.de

${ }^{23}$ See for example Christian Ramthun, "Die Neuen Deutschen," Wirtschaftswoche Nr. 1/2, January 4, 2001, pp. 16-25; Cordula Eubel, "Deutsche wollen doch reformen," Tagesspiegel July 6, 2002, p. 1; and hig, "Das Vertrauen in den Markt ist spürbar gewachsen" Frankfurter Allgemeine Zeitung May 24, 2002, p. 15.
} 
Some of the findings of this survey by the Bundesverband Deutscher Banken, dated April 2002, can be found in the appendix of this paper. ${ }^{24}$

Turning to the third indicator, myriad sources from within the employer groupings and the political sphere attest to the fact that the problem lies in the implementation of reforms, not in recognizing that reforms are necessary. As one leading politician, 2002 Christian-Democratic candidate for Chancellor Edmund Stoiber put it in the context of labor market deregulation: "We have no problem recognizing that reforms are necessary. We have a problem implementing those reforms." ${ }^{25}$ The governor of the Bundesland of Saxonia, Milbrandt, echoed this view: “We in Germany don't have a recognition, we have an implementation problem." ${ }^{26}$ The survey by the Bankenverband (see the appendix below), echoes this conclusion: "We certainly do not have a problem in Germany recognizing the need for reforms - we have a problem implementing them." ${ }^{27}$ To substantiate my argument that the implementation problem does not derive from "low employer interest, ${ }^{28}$ the next section describes a large-scale public relations campaign initiated and funded by German employers to expand their room of maneuver.

\footnotetext{
${ }^{24}$ Wilhelm Bürklin, Der Wirtschaftsstandort im internationalen Wettbewerb Demo/Skopie Nr. 14, Berlin: Bundesvaerband deutscher Banken, May, 2002.

25 "Erkenntnisprobleme haben wir nicht. Wir haben ein Durchsetzungsproblem." Statement by Dr. Edmund Stoiber, Christian Democratic candidate for Chancellor, at the meeting of the "Initiative Neue Soziale Marktwirtschaft," Hotel Maritim Pro Arte, Berlin, July 4, 2002.

${ }^{26}$ nf./reb., "Rot-Grün lehnt Gesetz zu Hartz-Vorschlägen vorerst ab" Frankfurter Allgemeine Zeitung, April 4, 2002, p. 1.

${ }^{27}$ Der Bankenverband Online, "Wirtschaftsstandort Deutschland: Die Bevölkerung ist für Reformen bereit” Der Bankenverband Online, April 10, 2002.
} 


\section{The 'New' Social Market Economy}

"At last at this point one could say: the new social market economy is identical with the Anglo-Saxon, the American principle [...]"29 -Hans Tietmeyer, former Bundesbank president and head of the 'New Social Market Economy' initiative ${ }^{30}$

What are the institutional preferences of German employers? In an initial attempt to answer this question, I examine a large-scale public relations campaign founded and funded by the three largest and most powerful German employers' associations: Gesamtmetall, the BDA, and the BDI. While we cannot directly read employer preferences off the rhetoric of this campaign - form and content may be modified by public-relations considerations - it is nonetheless probable that they do express something about what German employers want.

The campaign is titled the "neue soziale Marktwirtschaft" - the "New Social Market Economy' - despite the fact that its professed goal is actually a restoration of the 'old' social market economy. ${ }^{31}$ Which 'old' social market economy do the employers wish to create? The one that existed before it was 'hijacked' by special interest and redistributional groups. Already in 1958, when the social market was in its infancy, the Ordoliberal theorist Wilhelm Röpke thought that West German economic policy had taken a wrong turn. He declared that the state should place itself as a 'guardian of the market' above societal interest groups. ${ }^{32}$

\footnotetext{
${ }^{28}$ Stewart Wood, "Labor Market Regimes under Threat? Sources of Continuity in Germany, Britain, and Sweden,” p. 392 .

${ }^{29}$ Hans Tietmeyer, "Erhards Grundsätze sind nach wie vor richtig” Hans Tietmeyer, Die soziale Marktwirtschaft erneuern. Cologne: Chancen für alle, 2001, p. 22.

30 Tietmeyer, Die soziale Marktwirtschaft erneuern, p. 30.

${ }^{31}$ Interview with Dieter Rath, director of the Initiative Neue Soziale Marktwirtschaft, July 11, 2002

${ }^{32}$ Dieter Haselbach, Autoritärer Liberalismus und Soziale Marktwirtschaft Baden-Baden: Nomos Verlag, 1991, p. 172.
} 
The initiative "is sponsored by leading German business federations and aims to strengthen public awareness for the necessity to renew Germany's social market model." ${ }^{33}$ In doing so, the campaign seeks to connect with the founding myth of the Federal Republic of Germany. As Dieter Haselbach remarks:

[t]he social market economy' constitutes in part West Germany's self-consciousness; it forms the specific 'identity' of the West German people. In other words, the 'economic miracle' and the 'social market economy' constitute the founding myth of West Germany. ${ }^{34}$

The new social market campaign is non-partisan: It has ambassadors in all the major political parties, as well as several prominent public icons, university professors, businesspeople and workers. ${ }^{35}$ To support the initative, these figures appear in brochures, television and newspaper ads, and the Initiative's webpage (www.chancenfueralle.de), and speak at congresses organized by the initiative. Due to resource constraints, the initiative could only afford to target the population directly via television ads for a short time. The rest of the campaign myriad congresses, letters to the editor and ads in the print media - are addressed to 'multiplicators': persons who are in the position to affect public opinion and who can disseminate the message. The campaign is prolific in disseminating its doctrines; articles appear almost daily in major German

\footnotetext{
${ }^{33}$ Tietmeyer, Die Soziale Marktwirtschaft erneuern, p. 30. My italics.

${ }^{34}$ Dieter Haselbach, "Social Market Economy and West German Identity" Matthias Zimmer (ed.) Germany: Phoenix in Trouble? Edmonton: University of Alberta Press, 1997, p. 158. Emphasis added.

${ }^{35}$ Among these are Roland Berger, president of Roland Berger Consultants, and Hans Tietmeyer, former president of the Bundesbank.
} 
newspapers, and the reform message tends to be remarkably uniform across different new social market contributors. ${ }^{36}$

The campaign was started after a public opinion survey in the summer of 1999 showed evidence of growing estrangement from the economy and society. This estrangement manifested itself in the populace's growing distance and mistrust vis-à-vis business, as well as in deep-rooted differences in opinion regarding the future direction of economy and society. ${ }^{37}$ Roughly two-thirds of those surveyed in Germany viewed the prospect of upcoming economic reforms with attitude ranging from "skepticism" to "fear."38 The initiative was founded in order to help bring about a "Klimawechsel" - a change in the public opinion climate - which would facilitate the implementation of reforms employers desire and advocate. Recent surveys indicate that the tide of public opinion has turned in the direction favored by employers (see appendix). What are the desired reforms?

The campaign centers on the disjuncture between the historically evolved social market economy and its ideational origins. In addition to the political recognition of core sections of the labor movement and their integration into mechanisms of corporate governance, the post-war German political economy evolved an extensive welfare state with a dense network of regulations and generous income-replacement levels. This is the historically evolved social market economy. The ideational origins, however, are another matter

\footnotetext{
${ }^{36}$ See for instance Hans Tietmeyer, "Ein Blick zu unseren Nachbarn," Handelsblatt 12/13. April 2002, and Roland Berger, "Von anderen Ländern lernen," Handelsblatt 19/20 April 2002. It is striking that these two articles by different authors, appearing in the same newspaper within a week of each other, are almost identical.

${ }^{37}$ Chancen für Alle, Initiative Neue Soziale Marktwirtschaft Newsletter 1/2000, p. 4.
} 
altogether. ${ }^{39}$ As Gerhard Schwarz points out: "For him [Ludwig Erhard] the social market economy [...] was a sales formula, that should make clear that the market economy is itself social [that is, egalitarian or just]." ${ }^{40}$

The new social market campaign aims to engage with, and transform, prevailing societal norms of social justice. Perhaps in part a reaction to the tribulations of German history, these norms in postwar Germany have been marked by a high demand for security and a high sensitivity to income inequalities. The first component is that a social market is a free one, not one burdened by regulation and welfare-state interventionism. As Tietmeyer puts it, "the 'market economy' and 'the social' are erroneously seen by many as separate or opposed." ${ }^{\text {11 }}$ The campaign aims to "free up Erhard's original system from the shackles placed on it down the years." ${ }^{42}$

The second component is equality of results. The campaign advocates replacing distribution of resources with equality of opportunity: "Today it is no longer appropriate to promise Wohlstand [a certain level of material affluence] to everyone. The point is that everyone get a chance. ${ }^{43}$ As most clearly indicated by Tietmeyer's quote above ("the new social market economy is equivalent to the

\footnotetext{
${ }^{38}$ Gesellschaft im Zwiespalt: Marktwirtschaft und Unternehmer im Spiegel der öffentlichen Meinung Cologne: Deutscher Instituts Verlag, 2000, p. 16.

${ }^{39}$ Although one should emphasize that the traditions of Ordoliberalismus and Anglo-American free market liberalism are dissimilar in many respects.

${ }^{40}$ Quoted in Dieter Plehwe and Reinhard Walpen, "Wissenschaftliche und wissenschaftspolitische Produktionsweisen im Neoliberalismus" PROKLA, Vol. 29, Issue 115, No. 2, p. 224. I will leave open the extent to which the redistribution of wealth was integral to the ideational concept of the social market economy, or an element necessitated by cold-war regime competition. Alfred Müller-Armack, one of the 'founders' of the soziale Markwirtschaft in Germany, describes the class compromise as "reconciling the principle of market freedom with that of social equalization." See his “Soziale Marktwirtschaft," Handwörterbuch der Sozialwissenschaften, Vol. 9, Stuttgart, p. 390

${ }^{41}$ Tietmeyer, "Besinnung auf die Soziale Marktwirtschaft" Kirche und Gesellschaft Nr. 285, p. 11

${ }^{42}$ Hans Tietmeyer, "Germany Reborn: The Time Has Come to Renew Germany's Social Market Economic Model" Hans Tietmeyer, Die soziale Marktwirtschaft erneuern. Cologne: Chancen f· alle, 2001, p. 29. There are parallels here to the ungovernability discourse which has had currency in the Anglo-American countries since the 1970s and 1980s.

${ }^{43}$ Tietmeyer, Die Soziale Marktwirtschaft erneuern, op. cit., p. 22.
} 
American principle"), this campaign is in close company with deregulatory and 'free market' ideas propounded by many Anglo-American economists. Recent survey results indicate that the publicity efforts of the initiative have been remarkably successful in fostering greater pro-market sentiment among the populace (see the appendix for these results).

A third element deserves mention, though it is less prominent than the two discussed above: "Employees become co-entrepreneurs." "What is needed is the employee who thinks along, who as 'co-entrepreneur' partly assumes managerial responsibility. This is facilitated by the flat hierarchies of modern firms. ${ }^{45}$ This de-emphasis of the divide between employers and employees is neither an act of propaganda, nor of ideological obfuscation. Instead, I will show below how the increasingly widespread use of new management methods in the German political economy is blurring the divide between labor and capital, providing employees with the gains, as well as the burdens, of entrepreneurship.

For the sake of completeness, several other themes which grace the New Social Market Initiative's publications should be mentioned: the necessity of slimming down the state ${ }^{46}$; and of productive investments, rather than consumptive expenditures; the need to increase the public's willingness to tolerate greater income differentials ; the necessity of improved child-care facilities, so as facilitate the labor-market participation of women; the need for

\footnotetext{
${ }^{44}$ Michael Stahl, Uwe Claßen, Carsten Seim, Aufbruch in die neue Arbeitswelt Cologne: Chancen für Alle Themenheft Nr. 6, p. 8

${ }^{45}$ Aufbruch in die neue Arbeitswelt, p. 10.

${ }_{46}$ Andreas Wodock, Der schlanke Staat: Eine Fitnesskur für unser Gemeinwesen. Cologne: Deutscher Insituts-Verlag, 2001; and Moderner Staat; Schlanker Staat. Cologne: Chancen für Alle.
} 
flexibilization and deregulation in general, and of labor markets in particular ${ }^{47}$; and the creation of jobs as both the overriding goal of social policy and indeed, the principal requirement of social justice. "Badly paid jobs are better than none at all. [...] A guiding principal of the new social market economy is the motto: Just is whatever creates employment. ${ }^{\text {"48 }}$ The initiative thus draws attention to the fiscal strain caused by Germany's consistently high unemployment (each unemployed person costs the state approx. 19180 Euros annually). ${ }^{49}$ This fact, along with the demographic shift, necessitates urgent measures to raise the German employment rate. The alternative is the collapse of the existing system. ${ }^{50}$

The fact that this campaign has been initiated and is actively supported by the German employers' associations presents a puzzle, for it casts doubt on the structurally conservative employer preferences attributed to Germany in the "Varieties of Capitalism" literature. Perhaps part of this radicalism could be explained by reference to 'rhetorical surplus,' the idea that forceful rhetoric is necessary in order to achieve modest policy goals. ${ }^{51}$ But this still leaves the question of why German employers' rhetoric is frequently outside of the general institutional repertoire of 'coordination' specified by the Varieties literature. Rhetorical surplus cannot explain the paradox of the continued existence of the traditional institutions of the German model on the one hand, and on the other,

\footnotetext{
${ }^{47}$ Dieter Rath, "Die Job-Maschinen” Cologne: Chancen für Alle, 2000; Dr. Michael Stahl, Karsten Seim, "Mehr Freiheit, mehr Arbeit" Cologne: Chancen für Alle.

${ }^{48}$ Randolf Rodenstock, Chancen für Alle: Die Neue Soziale Marktwirtschaft Cologne: Deutscher Insituts-Verlag, 2001, pp. 54-55.

${ }^{49}$ Stefan von Borstel and Christoph B. Schiltz, "Jeder Arbeitslose kostet 19180 Euro" Die Welt July 1, 2002, p. 11

${ }^{50}$ Alexander Hagelücken, "Das Unsoziale am Sozialstaat," Süddeutsche Zeitung, March 8, 2002, p. 4.

${ }^{51}$ I am grateful to Heiner Ganßmann, who has elucidated this concept to me in several discussions.
} 
assertions that "we want more direction USA,"52 and lamentations of the absence of a Thatcher or Reagan on the German political scene. ${ }^{53}$

Despite the difficulties of interpreting the discourse of German employers, one would be mistaken to reject it as inconsequential or 'mere' rhetoric. Although these carefully selected examples above do not allow me to draw sweeping conclusions, pronouncements of this sort are surprising in light of the conventional view.

\section{A Paralyzing Employer Disunity?}

Kathleen Thelen's contributions to the study of German political economy have been particularly insightful and influential. In a 1999 article, Thelen argues that "German employers, not unions, are the ones suffering the greatest strategic and organizational disarray;"; 54 and that "Opponents of the system have structural difficulties in articulating a viable alternative within the context of existing structures," as noted above ${ }^{55}$ More recently, she has again asserted that "the tension within key employers' associations such as Gesamtmetall remains a serious threat to the system."

In what follows, I will attempt to show that the tensions within employers associations are less severe than Thelen claims. This is important for the argument of this paper: employer disarray, if severe, would preclude the

\footnotetext{
${ }^{52}$ Interview with Dieter Rath, director of the Initiative Neue Soziale Marktwirtschaft, July 11, 2002.

${ }^{53}$ See for example Heike Gabel, "Nichts von Thatcher oder Reagan," Frankfurter Allgemeine Zeitung, May 6, 2002, p. 13, and Thomas Knipp, "Gesucht: Ein Reformer" Handelsblatt, April 5/6, 2002, p. 11.

${ }^{54}$ Kathleen Thelen and Ikuo Kume, "The Effects of Globalization on Labor Revisited: Lessons from Germany and Japan" Politics \& Society Vol. 27, No. 4, December 1999, p. 489.

${ }_{55}$ Thelen, "Why Employers Cannot Bring Themselves to Dismantle the German Model," p. 163.

${ }^{56}$ Kathleen Thelen, "Varieties of Labor Politics" Peter A. Hall and David Soskice (eds.) Varieties of Capitalism Oxford: Oxford University Press, 2001, p. 85.
} 
articulation of viable alternatives to the traditional German model within existing structures, as I claim. This is not to dismiss the internal tensions emphasized by Thelen: Employers' associations officials confirm these, but only for the period from the early to the mid-1990s. ${ }^{57}$ The view that the tensions within the employers' camp, exhibited most vividly in the 1995 Bavarian strike and again in 1996, are permanent instead of episodic has not been confirmed by interviews with the relevant officials. Nor by recent statistics on association membership: these two years were aberrations, not the norm.

The present managing director of Gesamtmetall makes the point that the tensions following the 1995 strike in Bavaria were "not structural in nature, but rather the result of a failed bargaining strategy." ${ }^{.58}$ What happened in 1995 and 1996 was an isolated mistake, rather than one instance of a general trend. When the developments of recent years are compared to 1995-1996, Gesamtmetall's president Martin Kannegiesser's statement appears credible: "In general, in the last few years, the willingness [of firms] to stay in the employers' association has increased." ${ }^{59}$ Gesamtmetall's press director comments on the internal tension by saying that "this has been a non-topic since 1997 [...] unity has been restored." Although such statements by the organization about itself must be treated with caution, other sources confirm this view. An official from the federation of German employers' associations (BDA) has said that "this [association flight] was

\footnotetext{
${ }^{57}$ Interview with Martin Leutz, public relations speaker, Gesamtmetall, Cologne, July 17, 2002.

${ }^{58}$ Dr. Thomas Vajna, personal communication, July 18, 2002.

${ }^{59}$ Bernd Hops, Ursula Weidenfeld and Flora Wisdorff, "Wir erlauben uns keine Kampfrituale für Funktionäre"

[interview with Martin Kannegiesser] Der Tagesspiegel April 2, 2002.

${ }^{60}$ Interview with Martin Leutz, op. cit.
} 
a topic 3, 4, 5 years ago, but not anymore." ${ }^{61}$ Using Gesamtmetall data, I have compiled the development of wage costs and unit wage costs, and calculated the annual rate of association attrition of firms and employees from 1992 to 2001 (in percent): ${ }^{62}$

Year firms employees wage costs unit wage costs

$\begin{array}{llllr}1992 & -1.1 \% & -6 \% & +6.3 \% & 5.9 \% \\ 1993 & -4.1 \% & -10 \% & +7.1 \% & 6.1 \% \\ 1994 & -3.8 \% & -6 \% & +0.8 \% & -7.0 \% \\ 1995 & -4.9 \% & -4 \% & +3.9 \% & 3.7 \% \\ 1996 & -5.1 \% & -5 \% & +5.1 \% & -0.4 \% \\ 1997 & -3.4 \% & -2 \% & +1.0 \% & -5.5 \% \\ 1998 & -3.7 \% & -3 \% & +1.4 \% & -4.4 \% \\ 1999 & -3.1 \% & -2 \% & +3.3 \% & 0.4 \% \\ 2000 & -4.0 \% & -4 \% & +2.3 \% & -5.6 \% \\ 2001^{63} & -1.8 \% & -2 \% & +4.0 \% & 1.7 \%\end{array}$

Note that the figures under the columns 'firms' and 'employees' above do not indicate whether the firms or employees became insolvent or were fired, or simply left the association. Therefore, figures do not represent absolute values, and should be interpreted in relative terms in relation to each other.

The 2002 bargaining round resulted in wage increases of between three and four percent, far higher than most commentators and employers considered reasonable. But few firms left the employers' association as a result. One newspaper headline read "the big association flight doesn't occur." ${ }^{64} \mathrm{An}$ examination of the membership data presented above shows that the rapid decline in the number of firms and employees covered by sectoral collective bargaining was greatest from the early to the mid-1990s (especially in 1995 and

\footnotetext{
${ }^{61}$ Interview with Elmar Sulk, Bundesvereinigung der deutschen Arbeitgeberverbände, Berlin, July 23, 2002.

${ }^{62}$ See www.gesamtmetall.de or Die Metall- und Elektro-Industrie der Bundesrepublik Deutschland in Zahlen. Cologne: Gesamtmetall, 2002, sections 1.2 and 18.

${ }^{63} 2001$ figures for number of firms and employees include the combined rate of attrition for West and Eastern Germany; otherwise, the figures are for West Germany only.

${ }^{64}$ Rainer Nahrendorf, “Die große Tarifflucht bleibt aus” Handelsblatt June 14/15, 2002, p. 3.
} 
1996), and diminished thereafter. No strong relationship between association

flight and the central causal variable (wage cost increases) is apparent. Nor can

one see evidence that the union has succeeded in using just-in-time logistics to coerce employers into accepting high settlements. Some regional employers associations even report an increase in membership. ${ }^{65}$

Wolfgang Streeck's work corroborates the continuity of the collective …'bargaining system: "The rate of coverage of sectoral bargaining agreements has decreased around the edges, especially in Eastern Germany; but Germany still belongs to those countries in which the wages and working conditions of the overwhelming majority of employees are covered by sectoral bargaining agreements." ${ }^{16}$ I do not wish to imply that association flight is not a problem; it is. The collective bargaining partners are concerned about membership attrition and the declining coverage of sectoral bargaining agreements. But this problem does not constitute the central moment of erosion of the German model.

\section{Changing the Structure Through Content: The Paradigm Shift}

The continued existence and binding force of sectoral collective bargaining could lead one to underestimate the discontinuity of content in Germany despite the

\footnotetext{
${ }^{65}$ Niedersachsenmetall, the employers' association in Niedersachsen, claims this. Source: Kröncke, letter to the newspaper "Welt am Sonntag," August 5, 2002.

${ }^{66}$ Wolfgang Streeck, "Kontinuität und Wandel im deutschen System der industriellen Beziehungen: Offene Fragen" Arbeit, Vol. 10, No. 4, 2001, pp. 299-300. 66 percent of firms in the metal- and electrical industry belonged to employers' associations in 1964, compared to 43 percent in 1994. But during the same period, the proportion of employees covered by sectoral bargaining agreements dropped only from 77 to 66 percent. See Wolfgang Schröder and Rainer Weinert, "Anmerkungen zum Wandel industrieller Beziehungen in Deutschland: Kontrollierte oder unkontrollierte Dezentralisierung?" Zeitschrift für Politikwissenschaft. Vol. 9, Issue 4, 1999, p. 1305. More recent figures show that the proportion of firms across all sectors covered by sectoral bargaining agreements dropped from 47.7 to 45 percent between 1998 and 2000, the proportion of employees from 67,8 to 63 percent. But if one takes into account the firms and employees whose employment contracts are oriented towards the collective bargaining agreement (despite not being party to the agreement), the coverage is substantially higher, nearly two-thirds of firms and three-quarters of employees in Western Germany (the East is another matter altogether). See www.tarifvertrag.de
} 
apparent continuity of structure (institutions). Martin Höpner and Gregory

Jackson have the following to say about "institutional conversion:"

institutions can be used by persons and for goals that were not originally intended. While co-determination was originally seen as an institution to transform the German economy into an economic democracy, now, in a different context, it is used as an instrument to defend firms' class-overarching interests (co-management, micro-orientation). The jurisprudence governing co-determination has not changed, but the institution has. It hasn't collapsed, or come under serious political pressure. But the pressure of markets has creeped in so far that an activist of the 1970s wouldn't be able to recognize it. ${ }^{67}$

For Höpner and Jackson, the institution of co-determination has changed. Under today's circumstances, they assert, co-determination can only be considered nominally the same as it was during the 1970s. Similarly, when summarizing the findings of his numerous empirical case-studies, Klaus Dörre finds evidence of a "far-reaching transformation of firm-level labor relations within a formally intact institutional framework." ${ }^{\prime 8}$ A qualitatively new phenomenon in the German political economy can be located at the nexus of global competitive pressures and postfordist management methods. Whether these management practices are necessary to ensure the competitiveness of firms in Germany in global product markets is beyond the scope of this paper. But given their rapidly increasing incidence (see below), it appears that management deems them to be necessary; and from the standpoint of employers, they appear to be effective. ${ }^{69}$

\footnotetext{
${ }^{67}$ Martin Höpner and Gregory Jackson, "Das Deutsche System der Corporate Governance Zwischen Persistenz und Convergenz” Kölner Zeitschrift für Soziologie und Sozialpsychologie Vol. 54, No. 2, 2002, p. 364.

${ }^{68}$ Dörre, Kampt um Beteiligung, p. 401.

${ }^{69}$ G. Lay, C. Dreher, and S. Kinkel provide evidence that the new production organization is associated with substantially higher productivity and value-added than conventional methods. See their "Neue Produktionskonzepte leisten einen Beitrag zur Sicherung des Standorts Deutschland" Frauenhofer Institut Systemtechnik und Innovationsforschung PI-Mitteilungen Nr. 1, July 1996.
} 
The new phenomenon has been variously termed "indirect control,",70 "market-centered control mode,"71 and the emergence of the "labor-power salesperson." ${ }^{72}$ It is a paradigm shift, rather than merely a transient management fad, because it corresponds to a far-reaching transformation of the mode of production of advanced capitalist societies. As Dieter Sauer remarks: "The relation of [the financial] market and production has changed. The subordination of the market to the requirements of production has been reversed: The market now becomes the essential point of reference point for all processes within firms, under the notion of 'customer orientation' more and more structures within firms are marketized." ${ }^{73}$ I begin by delineating the concept underlying this development, before proceeding to empirics.

According to the works council of IBM Düsseldorf, Wilfried Glißmann, the origins of this shift can be traced to management strategists of the mid-1980s, who in turn borrowed ideas from Japan: General Electric CEO Jack Welch, IBM's Lou Gerstner, and ABB's Percy Baranevik. In the 1990s, many German firms adopted these strategies ${ }^{74}$ variously termed Activity Costing, Target Costing, Business Reengineering, and Just-in-Time. ${ }^{75}$ The reception of these ideas was greatly expedited in Germany by the broad reception of James Womack, Daniel

\footnotetext{
${ }^{70}$ see Wilfried Glißmann and Klaus Peters, Mehr Druck durch mehr Freiheit. Hamburg: VSA-Verlag, 2001.

${ }^{71}$ see Klaus Dörre, Kampf um Beteiligung. Wiesbaden: Westdeutscher Verlag, 2002.

${ }^{72}$ G Günther Voß and Hans J. Pongratz, "Der Arbeitskraftunternehmer” Kölner Zeitschrift für Soziologie und Sozialpsychologie Vol. 50, No. 1, 1998, pp. 131-158. The following discussion is drawn from Günther Voß, Hans Pongratz, Klaus Peters, Wilfried Glißmann, and Klaus Dörre to describe the paradigm shift in the German political economy,

${ }^{73}$ Dieter Sauer, “Grenzen Setzen - aber wie? Das Dilemma der Arbeitszeitgestaltung” Beitrag zum Forum 'Arbeiten ohne Ende' auf der arbeitspolitischen Konferenz der IG Metall vom 24-26. Oktober in Mannheim.

${ }^{74}$ Wilfried Glißmann, personal communication, September 16, 2002.

${ }^{75}$ See Wilfried Glißmann and Angela Schmidt, Mit Haut und Haaren: Der Zugriff auf das ganze Individuum. Frakfurt: IG Metall, May 2000.
} 
Jones, and Daniel Roos's book The Machine That Changed The World. ${ }^{76}$ The new management strategies in Germany thus come under the broad heading of 'Lean Production,' the organizational and manufacturing techniques which have become widespread in Japanese and North American industry. An important agenda for future research will be to ascertain whether and in which ways the German adaptations of Lean Production are distinctive. ${ }^{77}$

The reception of The Machine That Changed The World in Germany coincided with the severe post-reunification recession of the early 1990s, which further impelled the adaptation of 'Lean' rationalization strategies by company management (at this time, capital markets were not the driving force).$^{78}$ The early 1990s are the 'turning point' which initiated the shift towards 'indirect control.' The new strategies were adopted by small- and medium-sized as well as large firms, according to industrial sociologist Christoph Deutschmann. ${ }^{79}$ Schaumburg et. al. describe the move towards flexibilization during the 1990s as follows: "while at the beginning of the 1990s the question was still posed why firms made such limited use of their [flexibilization] leeway, by the end of the 1990s the situation had changed fundamentally. Newer studies have shown that many firms are pushing to and even beyond the flexibilization provisions contained in sectoral collective bargaining contracts." 80

\footnotetext{
${ }^{76}$ James P. Womack, Daniel T. Jones, and Daniel Roos, The Machine That Changed The World: The Story of Lean Production New York: HyperPerennial, 1991.

${ }^{77}$ There are reasons to believe they are, especially with regard to the use of flexible working time regimes (such as working-time accounts and the outright abolition of the time clock; more on this below).

${ }^{78}$ Christoph Deutschmann, personal communication, November 5, 2002

${ }^{79}$ Christoph Deutschmann, personal communication, November 5, 2002.

${ }^{80}$ Stefan Schaumburg, Hilde Wagner, Steffen Lehndorff and Thomas Haipeter, Arbeitszeitregulierung in der deutschen Automobilindustrie Frankfurt: IG Metall Grüne Reihe Nr. 10, August 2002, p. 5.
} 
The new development is double-edged. On one hand, the autonomy of employees to work as they wish is increased; paternalistic and hierarchical rules of the Fordist era are abolished. ${ }^{81}$ This is an important gain for employees, compared with the vagaries of Taylorism. But along with this newly found autonomy "the performance pressure is massively increased." ${ }^{82}$ Rather than purchasing labor power, employers are moving more and more towards purchasing finished products from their employees. The result of this, as Voß and Pongratz remark, is the "systematically increased self-control of the workers," 83 even a "colonization of the will" of the employee by economic rationality. ${ }^{84}$ The 'labor power salesperson' displaces the external opposition of labor and capital into the employee him or herself. As Voß and Pongratz put it:

The labor power salesperson assumes such far-reaching controland management functions, that s/he, as hitherto only management, has almost switched camps and his/her objective interests as laborpower are hard to recognize. Nevertheless, the conflict of interests between labor and capital reappears in unexpected form. Because the labor-power salesperson aligns him/herself with the firms' interests to such a far-reaching extent and controls the transformation of his/her labor power into labor, s/he brings the conflict of interest within him/herself. [...] The conflict of interest appears less and less in the form of the industrial era between labor and capital, and more and more between two sides of one and the same person -- the class struggle is transplanted within the heads and souls of employees. ${ }^{85}$

\footnotetext{
${ }^{81}$ This sweeping claim is not without counter evidence. On the re-introduction of Taylorist production methods in German industry, see Klaus Dörre,, Klaus Pickshaus and Rainer Salm, Re-Taylorisierung. Supplement der Zeitschrift Sozialismus 9/2001.

${ }^{82}$ Voß and Pongratz, p. 134.

${ }^{83}$ Voß and Pongratz, p. 132. According to Chris Tilly and Charles Tilly, the span of control in Germany during 1980 was considerably lower than in the Anglo-American countries. The new management methods may further strengthen this comparative advantage. See Chris Tilly and Charles Tilly, Work under Capitalism Boulder: Westview Press, 1998, p. 205.

${ }^{84}$ These examples derive in part from "Meine Zeit ist mein Leben," Denkanstösse - IG Metaller in der IBM. Frankruft: IG Metall, 1999, p. 49.

${ }^{85}$ Voß and Pongratz, p. 152.
} 
One area in which indirect control methods are widespread is the management of working time. In December, 1998, IBM's German offices stopped monitoring the working time of their employees. With few restrictions, they were free to come and go as they pleased between 6am and 8pm. Rather than being confronted with their firm's bureaucratic framework and the hierarchies of management, employees were confronted with the unmediated market itself; or rather, with management's staging of that market. Workers in groups are fearful of leaving their workplace, because the remaining workload will fall as a burden upon their colleagues; the increase of stringent profitability objectives prompts employees to view their less efficient colleagues as 'slackers,' rationalizable in the service of rescuing their division or firm from the threat of closure and relocation. ${ }^{86}$

Such instances of labor recommodification have proceeded furthest in highly skilled, knowledge-intensive services - the competitive edge of deregulated Liberal Market Economies. But they are increasingly widespread in the heartland of German manufacturing as well. Klaus Dörre's exhaustive study provides an insightful survey of participatory management initiatives in German industry during the 1990s. One worker in a transformer-manufacturing plant describes the situation as follows:

Management doesn't care about how individuals do their work. They say: 'you have to arrange your place of work in such a way that you can become efficient, and if you can't, then bad luck, then we can't hold the job, the division!' Now the colleagues [workers] do the [process] optimization almost all by themselves [...] but the position of labor is weak, because in the last instance, the jobs are always in danger. And extortion, I can't find a better word for it, is now on the daily agenda: 'either you do it, or we have to shut down here, move

\footnotetext{
${ }^{86}$ These examples derive in part from "Meine Zeit ist mein Leben," Denkanstösse - IG Metaller in der IBM. Frankruft: IG Metall, 1999.
} 
out, globalize!.' [...] It is now the case that we compete with Eastern

Europe and our costs are lower. And still we get no peace ${ }^{87}$

How widespread is this new phenomenon? As of yet, only limited evidence can be found for these developments in existing labor market statistics. Some observers infer from this that the phenomenon is marginal. However, as Manfred Moldaschl observes about labor market statistics:

The current categories are naturally not in the position to grasp what is going on within their categorization. One cannot hold this against them, only against those who hold that the 'within' is irrelevant [...] Labor market categories are similar to geography: Austria also lies within the boundaries of 1945 . But is it still the same $?^{88}$

Attempts to operationalize these recommodification phenomena are fraught by difficulties. First, observers do not agree amongst themselves on what is distinctive of the new phenomena. ${ }^{89}$ Second, operationalization presents methodological problems. For example, as a consequence of 'indirect control,' the length of the working day is no longer monitored in a growing number of firms. As a result, in the place of reliable statistics about working time we have only the self-reports of individual employees (and even these are not collected systematically). ${ }^{90}$ Nevertheless, there are three proxy measures which may provide some insight: The incidence of group work, working-time accounts, and the introduction of goal- or market-based remuneration systems.

According to Jürgen Nordhause-Janz and Ulrich Pekruhl, the incidence of group work (strictly defined) increased by over 70\% between 1993 and 1998,

\footnotetext{
${ }^{87}$ Dörre, Kampf um Beteiligung, p. 358.

${ }^{88}$ Manfred Moldaschl, "Unternehmergesellschaft oder McDonaldisierung? Zum formellen und inhaltlichen Wandel des Beschäftigungsverhältnisses," unpublished manuscript, 2002.

${ }^{89} \mathrm{Jörg}$ Ständlinger, personal communication, November 20, 2002.

${ }^{90}$ Klaus Peters, personal communication, August 5, 2002.
} 
from $6.8 \%$ of all employees in 1993 to $11,8 \%$ in 1998 , with a continuing upward trend. ${ }^{91}$ Group work is likely to be associated with, but is not a necessary prerequisite of, Management by Objectives (MbO). For example: In Volkswagen's new $5000 \times 5000$ project, groups of workers receive a set rate to manufacture a preordained quantity and quality of minivans. Should they fail to achieve these objectives, they must work longer (without any extra remuneration) until they achieve these goals. However, while group work almost invariably implies $\mathrm{MbO}$ and 'indirect control,' the latter do not necessarily imply group work; thus, their prevalence almost certainly exceeds that of the figures quoted above. A second proxy indicator is working-time accounts. Unlike rigid working time, working time accounts allow working hours to be spread unevenly in accordance with the firms' and employees' needs. For example: During times of peak demand, an employee puts in forty-eight hours without overtime pay; during times of weak demand, she puts in thirty-two hours. Working-time accounts make labor much more flexible and 'close' to market demands and fluctuations, and reduce the incidence of costly overtime pay for firms. "In the past three years, the percentage of firms which use working time accounts has increased by ten percentage points, the percentage of employees, by seven percentage points. In the year $2001,29 \%$ of all firms used working time accounts; $40 \%$ of employees currently hold working time accounts. ${ }^{\text {92 }}$ Since they continue to count labor time as a yardstick for remuneration, working-time accounts are a weaker form of

\footnotetext{
${ }^{91}$ Jürgen Nordhause-Janz and Ulrich Pekruhl, "Managementmoden oder Zukunftskonzepte? Zur Entwicklung der Arbeitsstrukturen und von Gruppenarbeit in Deutschland" Jürgen Nordhause-Janz and Ulrich Pekruhl (eds.) Arbeiten in neuen Strukturen? Partizipation, Kooperation, Autonomie und Gruppenarbeit in Deutschland Mering: Rainer Hampp Verlag, 2002, p. 43;66.

${ }^{92}$ ISO-Informationen 12/2002, 9-11. "Arbeits- und Betriebszeiten 2001"
} 
flexibilization and recommodification than the other variations of work organization discussed in this paper; but like these other forms, they aim to make labor power as flexible and readily available as water out of a faucet.

Reinhard Bahnmüller's work on remuneration systems is also helpful in this respect. According to Bahnmüller, there is a close connection between 'indirect control' and the introduction of goal- and market-based remuneration systems. These remuneration systems make employee pay contingent on the realization of their labor power in the market, or on the attainment of performance-based goals. ${ }^{93}$

According to Bahnmüller's 1998 survey, 61 percent of firms in the metaland electrical, textile, clothing, and banking industries employed performancebased pay systems, comprising between 11 and 30 percent of blue collar pay, 7 and 22 percent of white collar pay, and between 8 and 30 percent of executive remuneration, with an upward tendency. ${ }^{94}$ By contrast, in Great Britain, commonly taken to be an exemplar of marketized flexibility, only six percent of employee pay was tied to performance-based pay systems. Other sources suggest that indirect control is widespread in the domain of highly paid professionals; but as as Dörre shows, it is also a prominent trend in German manufacturing.

At this point, it cannot be ruled out as a hypothesis that the introduction of new management and production concepts, while associated with deleterious

\footnotetext{
${ }^{93}$ In contrast to the regimentation and aspirations of 'total control' which were characteristic of Taylorist production and remuneration methods. The affinity of performance-based remuneration systems and indirect control was made to me by Reinhard Bahnmüller, personal communication, September 11, 2002.
} 
effects for employees, has had the effect of shoring up employer unity. Lay, Dreher and Kinkel provide an example of how new production concepts can disproportionately benefit smaller firms ${ }^{95}$ As noted above, Deutschmann has noted that small-, as well as medium- and large-sized firms adopted elements of the new management strategies in order to overcome what they perceived as excessively bureaucratized firm structures.

Skeptics can deny the significance of these developments by pointing to the continued existence of traditional institutions of the German model, such as works councils. Will these multifarious MbO-recommodification initiatives lead to the dismantling of these institutions? Probably not in the near future. But it may render them insignificant and ineffectual as guarantors of employee rights.

Haipeter et. al.'s passage is worth quoting at length:

The question arises, what tasks remain for the works council when the working time is no longer monitored, because a large part of its bargaining power, as far as this is based upon the works council constitution act [Betriebsverfassungsgesetz], depends upon influence over prolongation or shortening of the firm's working time [...] but even if working time is monitored by employees, as we have seen above, 'no employee demands vis-a-vis the employer can thereby be derived' [...] as an institutional counter-weight to management, the works council is the prerequisite of a 'culture of trust' [Vertrauenskultur] within the firm, but because the works council can no longer use the works council constitution act [under conditions of the non-monitoring of working time], this prerequisite erodes. Employees gain autonomy in their work; but they loose negotiating power, which in turn undermines their autonomy. This opens the door to a lengthening of working time. ${ }^{96}$

\footnotetext{
${ }^{94}$ Reinhard Bahnmüller, Stabilität und Wandel in der Leistungsentlohnung, WSI Mitteilungen 7/2001, p. 426. For a more detailed discussion, see Bahnmüller, Stabilität und Wandel in der Entlohnungsformen. Munich and Mering: Rainer Hampp Verlag, 2001.

${ }^{95}$ G Lay, C. Dreher and S. Kinkel, "Neue Produktionskonzepte leisten einen Beitrag zur Sicherung des Standorts Deutschland" Frauenhofer Institut Systemtechnik und Innovationsforschung PI-Mitteilungen Nr. 1, July 1996, pp 9-11.

${ }^{96}$ Thomas Haipeter, Steffen Lehndorff, Gabi Schilling, Dorothea Voss-Dahm and Alexandra Wagner,

"Vertrauensarbeitszeit: Analyse eines Rationalisierungskonzeptes" Leviathan Heft 3, September 2000, pp. 375; 377; 380 .
} 
If employees are free to choose their hours under the new regimes of Vertrauensarbeitszeit (working time on the basis of trust) and wish to work shorter hours, the obvious question is: Why don't they simply work less? Some employees may choose to work long hours, but MbO makes it difficult for these employees to reduce their hours, as Haipeter et. al. explain: "When they again desire shorter hours, be it for health reasons, or because other aspects of life become more important to them, they will have great difficulties to realize these desires. They have to present their position not to a firm hierarchy, but to the 'market.' They cannot simply convince their superior or colleagues of their need; they have to convince 'the competition."'97

So far-reaching is the transformation described by Haipeter et. al., that works councils under the new conditions no longer pose the counterbalance to capital which provides the foundation for the German model. This is the basis for my claim that the introduction of the aforementioned management and organizational methods challenges the German model at its core. The German model cannot simply equal sectoral collective bargaining + works councils. To consider the German model this way is to fetishize institutions. At core, what is distinctive about the German model is the rights and privileges these institutions provided for employees in particular and for the populace in general, without sacrificing economic efficiency. ${ }^{98}$

\footnotetext{
${ }^{97}$ Thomas Haipeter, Steffen Lehndorff, Gabi Schilling, Dorothea Voss-Dahm and Alexandra Wagner, "Vertrauensarbeitszeit: Analyse eines Rationalisierungskonzeptes," p. 375.

${ }^{98}$ According to Heinz Tüselmann and Arne Heise, the German system "provided employees with one of the highest earning levels, shortest working hours, most generous holiday and benefits entitlements in the industrialized world." See their "The German model of industrial relations at the crossroads: past, present and future" Industrial Relations Journal Vol. 31, No. 3, p. 166. Stephen J. Silva remarks that "two distinguishing features of West Germany for the
} 
Organized labor's response to employers' new strategies has so far been muted. The union movement is split between 'traditionalist' (represented by IG Metall's Jürgen Peters) and 'modernizing' poles (represented by IG Metall's Berthold Huber). ${ }^{99}$ This disjointed response of labor, and vigorous debates between modernizer and class-conscious poles of the union movement, contrasts with the relatively unified stand of employers: Thelen's claim that capital (rather than labor labor) suffers the greatest internal discord, while true during the mid-1990s, is no longer accurate. The situation is, if anything, the opposite of what she described: labor, hobbled by internal dispute, now faces a united front of firms.

Labor's discordant response can easily be explained if the new strategies are a prerequisite of firms' competitiveness. In addition, many of the new developments do have plusses for workers, making a unified stand against the changes difficult. Given current rates of membership decline, organized labor cannot afford to stake out a position which incurs substantial costs on this account. Wolfgang Trittin, a close observer of the industrial union IG Metall, confirms that the goals of securing existing production locations and competitiveness enjoy top priority. ${ }^{100}$ According to Trittin, IG Metall has yet to respond at the organizational level: "very many find indirect steering to be 'modern' and a good alternative to old organizational concepts. Whoever within IG Metall finds 'indirect steering' to be problematic, does not yet see a viable

majority of its brief history were the remarkably high quality of most jobs and the relative evenness of income distribution." See Silva's "Political Adaptation to Growing Labor Market Segmentation" Lowell Turner (ed.) Can Social Partnership Survive? Negotiating the New Germany Ithaca: Cornell University Press, 1997, p. 157.

${ }^{99}$ Alexander Hagelüken, “Lautlos in den Kampf” Süddeutsche Zeitung April 16, 2002, p.3.

${ }^{100}$ WolfgangTrittin, Telephone Interview. December 5, 2002. 
alternative."101 This does not mean, however, that unions have not struggled to come to terms with the new management forms.

Under one new agreement between Volkswagen and IG Metall called $5000 * 5000,{ }^{102}$ the employers had aimed to remunerate their employees exclusively according to agreed-upon production targets - working time (and the power of the works council) would have become the variable by-product of employee success (or lack thereof) at achieving these goals. As Schaumburg et. al. acknowledge, "flexibilization would have led to deregulation." ${ }^{103}$ Although the employers did not entirely get their way, employees are now liable for mistakes and product imperfections, which they must make up on their own time and without additional pay. ${ }^{104}$ Under the threat of dis-investment from German production locations, the union succeeded in fending off management's offensive strategy.

There are other examples of promising union initiatives. Wilfried Glißmann, IG Metall works council at IBM Düsseldorf, is at the forefront of innovative responses to the new management strategies in the area of skilled services. In 1997, Glißmann helped initiate a project termed "ich besinne mich" 'I reflect upon my own situation.' This may seem innocuous compared with traditional labor strategies such as strikes; but this perception is mistaken. Management prohibited the event. ${ }^{105}$ In the end, the 'reflection' initiative did proceed, soliciting anonymous responses from employees about their

\footnotetext{
${ }^{101}$ Wolfgang Trittin, personal communication, November 14, 2002.

${ }^{102}$ Because 5000 unemployed persons were to be hired earning 5000 Deutschmarks per month building minivans.

${ }^{103}$ Stefan Schaumburg, Hilde Wagner, Steffen Lehndorff and Thomas Haipeter, Arbeitszeitregulierung in der deutschen Automobilindustrie Frankfurt: IG Metall Grüne Reihe Nr. 10, August 2002, p. 51.

${ }^{104}$ Volkswagen's project ' $5000 \times 5000$ ' to build minivans is one example.
} 
experiences through the firm's intranet. As Glißmann puts it, "these new management forms live from unreflectiveness. One is not supposed to grasp what is happening to oneself. That is why reflection is the most rigorous response [to management]." ${ }^{106}$ And Alexandra Wagner explains that while employers currently have the upper hand, traditional institutions of the German model such as works councils and labor law constitute a platform from which to launch attempts at re-regulation. ${ }^{107}$

In sum, indirect control is Janus-faced. The increased autonomy within work can be liberating, but this contrasts with greatly increased performance pressure and economization, which in their more extreme manifestations are transforming Germany's postwar settlement. But Peters, a philosopher who has led several union initiatives to thematize and understand 'indirect steering,' is adamant: 'I am of the view that one must absolutely welcome the dismantling of [Fordist, Taylorist] command-and-control structures -- but not, as the optimists claim, because this results in a humanization of work, but even though tendentially the opposite is the case." 108

\section{Conclusion}

In this paper, I have argued that the transformation of German productive relations has been more far-reaching than previously thought. Flexibilization and workplace autonomy can be likened to a Trojan Horse transforming Germany's postwar settlement; or to the figure of Oscar Wilde's Dorian Grey, whose external appearance remains unchanged while undergoing fundamental internal

\footnotetext{
${ }^{105}$ Michaela Böhm, "Seid profitabel!" [interview with Wilfried Glißmann] metall 1/2000, p. 13.

${ }^{106}$ Wilfried Glißmann, Michaela Böhm, "Seid profitabel!” [interview with Wilfried Glißmann] metall 1/2000, p. 13.
} 
transformations. The established wisdom is that flexibility within a stable institutional framework explains the resilience of the German model. But there comes a point at which the framework itself is transformed.

Although German employers do not desire the wholesale abolition of sectoral collective bargaining or co-determination (they do want labor representatives removed from firms' supervisory boards), ${ }^{109}$ the continued existence of these institutions should not be conflated with a continuity of outcomes or results. We do not value institutions for their own sakes, but rather for what they deliver. If it is true, as the "Varieties of Capitalism" literature asserts, that employers will tend to retain production sites requiring 'coordination' and highly-skilled labor within Germany, this paper also makes clear that retaining these activities against the threat of disinvestment and relocation comes with substantial costs for employees. Hall and Soskice's excessive firm-centrism blinds them to these changes.

To make the case in favor of persisting divergence between Coordinated and Liberal Market Economies, as the "Varieties" literature seeks to do, it is not sufficient to show that firms in CMEs such as Germany support mechanisms of coordination. It is crucial to look inside of mechanisms and institutions, at the management and production paradigms which constitute the space within. The exploratory evidence compiled in this paper suggests that in contrast to longstanding tradition, managers in German firms are increasingly employing marketcentered management strategies. Corporate governance is becoming

\footnotetext{
${ }^{107}$ Alexandra Wagner, personal communication, January 22, 2003.

${ }^{108}$ Klaus Peters, "Die Neue Autonomie in der Arbeit," Peters and Glißmann, Mehr Druck durch mehr Freiheit, p. 28.
} 
increasingly market-driven. Indeed, all of the new management initatives surveyed in this paper are finance- and market-centered as never before. Future research should more closely examine the management paradigms which are bringing about these effects, and which are the actual foundation of industrial restructuring in Germany today.

The fate of the German model will depend upon whether employees can be mobilized to re-establish a new positive-sum class compromise, and upon whether such a compromise is possible under the duress of global competition. Labor's strategy in these hard times can be gleaned from a recent IG Metall brochure: "first: each person must reflect upon what is good for him or her. Second: no one can do this in isolation from each other!" ${ }^{110}$ The future of the German model is not a foregone conclusion - even as employers apply pressure from without, and subvert structure from within.

\footnotetext{
${ }^{109}$ Interview with Jan Wulfetange, BDI expert on matters of corporate governance, Berlin, July 2002.

${ }^{110}$ Klaus Peters, "Woher weiß ich, was ich selber will?" Meine Zeit ist mein Leben, p. 10.
} 


\section{Appendix}

The Survey: "Economic Location Germany: The Populace is Ready for reforms"111

Social Market Economy: in future we need...

$\begin{array}{lcc} & \text { October 2001 } & \text { Februrary } 2002 \\ \text { more market } & 27 & 41 \\ \text { more welfare state compensation } & 48 & 37 \\ \text { no changes } & 22 & 14 \\ \text { don't know } & 4 & 7\end{array}$

Author's note: it is important to distinguish between former West- and East Germany. In the east, $54 \%$ of respondents favored more welfare state compensation, $34 \%$ an expansion of market mechanisms -- a response attributable to socialization in the German Democratic Republic as well as the economic weakness of eastern regions. In the west, $43 \%$ of respondents favored an expansion of market mechanisms, and only $33 \%$ more welfare state compensation.

To ensure wealth for all, is first and foremost...

responsibility

of individual

responsibility

of the state

don't know
May 1994 Feb $1996 \quad$ March 2000

47

47

6
44

49

7

Feb 2002

For the economic development of a country it is best if the state intervenes as little as possible in the economy"

$\begin{array}{lcl}\text { agree completely } & 21 & \\ \text { somewhat agree } & 29 & >49 \text { agree } \\ \text { disagree on the whole } & 33 & \\ \text { disagree completely } & 11 & >44 \text { disagree } \\ \text { don't know } & 7 & \end{array}$

Are too many aspects of the economy regulated by the state? too much regulation 55 not enough regulation 38 don't know

\footnotetext{
${ }^{111}$ Wilhelm Bürklin, Der Wirtschaftsstandort im internationalen Wettbewerb Demo/Skopie Nr. 14, Berlin: Bundesvaerband deutscher Banken, May, 2002.
} 


\section{Bibliography}

Albert, Michel. Capitalism vs. Capitalism. New York: Four Walls Eight Windows, 1993.

Bahnmüller, Reinhard. Stabilität und Wandel in der Entlohnungsformen. Munich and Mering: Rainer Hampp Verlag, 2001.

Bahnmüller, Reinhard. Stabilität und Wandel in der Leistungsentlohnung, WSI Mitteilungen 7/2001, pp. 426-433.

Bergmann, Joachim. "Die negative Utopie des Neoliberalismus oder die Rendite muß stimmen" Leviathan. Vol. 26, No. 3,

Böhm Michaela. "Seid profitabel!" [interview with Wilfried Glißmann] metall 1/2000, pp. 11-13.

Breise, Marc. “Der Hartspüler” Süddeutsche Zeitung July 6/7, 2002, p. 25.

Bürklin, Wilhelm. Der Wirtschaftsstandort im internationalen Wettbewerb Demo/Skopie Nr. 14, Berlin: Bundesvaerband deutscher Banken, May, 2002.

Cox, Robert Henry. "The Social Construction of an Imperative: Why Welfare Reform Happened in Denmark and the Netherlands but Not in Germany" World Politics, April 2001, pp. 463-498.

Deutschmann, Christoph. personal communication, November 5, 2002.

Deutschmann, Christoph. "Die Gesellschaftskritik der Industriesozologie -- ein Anachronismus?" Leviathan Vol. 29, Issue 1, March 2001, pp. 58-69.

Die Metall- und Elektro-Industrie der Bundesrepublik Deutschland in Zahlen. Cologne: Gesamtmetall, 2002.

Dörre, Klaus. Kampf um Beteiligung. Wiesbaden: Westdeutscher Verlag, 2002.

Dörre, Klaus, Klaus Pickshaus and Rainer Salm, Re-Taylorisierung. Supplement der Zeitschrift Sozialismus 9/2001.

Ganßmann , Heiner and Michael Haas, "Eurosklerose?" PROKLA Vol. 29, Issue 114, No. 1, pp. 55-71.

Glißmann and Angela Schmidt, Mit Haut und Haaren: Der Zudriff auf das ganze Individuum. Frakfurt: IG Metall, May 2000. 
Gesellschaft im Zwiespalt: Marktwirtschaft und Unternehmer im Spiegel der öffentlichen Meinung Cologne: Deutscher Instituts Verlag, 2000.

Glißmann, Wilfried and Klaus Peters. Mehr Druck durch mehr Freiheit. Hamburg: VSA-Verlag, 2001.

Haipeter, Thomas, Steffen Lehndorff, Gabi Schilling, Dorothea Voss-Dahm and Alexandra Wagner, "Vertrauensarbeitszeit: Analyse eines Rationalisierungskonzeptes" Leviathan Heft 3, September 2000, pp. 360383.

Hall, Peter A. and David Soskice (eds.) Varieties of Capitalism Oxford: Oxford University Press, 2001.

Hall, Peter A. and David Soskice, "An Introduction to Varieties of Capitalism," Peter A. Hall and David Soskice (eds.) Varieties of Capitalism, pp. 1-68.

Haselbach, Dieter. "Social Market Economy and West German Identity" Matthias Zimmer (ed.) Germany: Phoenix in Trouble? Edmonton: University of Alberta Press, 1997, pp. 157-182

Höpner, Martin and Gregory Jackson, "Das Deutsche System der Corporate Governance Zwischen Persistenz und Convergenz" Kölner Zeitschrift für Soziologie und Sozialpsychologie Vol. 54, No. 2, 2002, pp. 362-368.

ISO-Informationen (2002) 12/2002, 9-11. "Arbeits- und Betriebszeiten 2001"

Katzenstein, Peter J. "Stability and Change in the Emerging Third Republic" Peter J. Katzenstein (ed.) Industry and Politics in West Germany Ithaca: Cornell University Press, 1989, pp. 307-353.

Lay, G, C. Dreher and S. Kinkel, "Neue Produktionskonzepte leisten einen Beitrag zur Sicherung des Standorts Deutschland" Frauenhofer Institut Systemtechnik und Innovationsforschung PI-Mitteilungen Nr. 1, July 1996.

Leben und Arbeiten in Deutschland: Mikrozensus 2001 Statistisches Bundesamt.

Manow, Philip. "Comparative Institutional Advantages of Welfare State Regimes and New Coalitions in Welfare State Reforms" Paul Pierson (ed.) The New Politics of the Welfare State, New York: Oxford University Press, pp. 146164.

Moldaschl, Manfred. “Unternehmergesellschaft oder McDonaldisiierung? Zum 
formellen und inhaltlichen Wandel des Beschäftigungsverhältnisses," unpublished manuscript, 2002.

Nordhause-Janz, Jürgen and Ulrich Pekruhl. "Managementmoden oder Zukunftskonzepte? Zur Entwicklung der Arbeitsstrukturen und von Gruppenarbeit in Deutschland" Jürgen Nordhause-Janz and Ulrich Pekruhl (eds.) Arbeiten in neuen Strukturen? Partizipation, Kooperation, Autonomie und Gruppenarbeit in Deutschland Mering: Rainer Hampp Verlag, 2002, pp. 13-68

Rodenstock, Randolf. Chancen für Alle: Die Neue Soziale Marktwirtschaft. Cologne: Deutscher Instituts Verlag, 2001.

Offe, Claus, Susanne Fuchs, Gert Wagner and Hans-Jürgen Krupp, "Zurück in die Zukunft: Stellungsnahmen zum dritten Bericht der MiegelKommission," Blätter für deutsche und internationale Politik, Issue 3, 1998, pp. 295-311

Rath, Dieter. [Director of the Initiative Neue Soziale Marktwirtschaft.] Interview. July 11, 2002.

Sauer, Dieter. "Grenzen Setzen - aber wie? Das Dilemma der Arbeitszeitgestaltung" Beitrag zum Forum 'Arbeiten ohne Ende' auf der arbeitspolitischen Konferenz der IG Metall vom 24-26. Oktober in Mannheim.

Schaumburg, Stefan, Hilde Wagner, Steffen Lehndorff and Thomas Haipeter, Arbeitszeitregulierung in der deutschen Automobilindustrie Frankfurt: IG Metall Grüne Reihe Nr. 10, August 2002.

Schröder, Wolfgang and Rainer Weinert. "Anmerkungen zum Wandel Industrieller Beziehungen in Deutschland: Kontrollierte oder unkonntrollierte Dezentralisierung?" Zeitschrift für Politikwissenschaft. Vol. 9, Issue 4, 1999, p.

Silva, Stephen J. "Political Adaptation to Growing Labor Market Segmentation" Lowell Turner (ed.) Can Social Partnership Survive? Negotiating the New Germany Ithaca: Cornell University Press, 1997, pp. 157-176.

Ständlinger Jörg. Personal communication. November 20, 2002.

Steinke, Rudolf (ed.) "Die Sackgassen der Zukunftskommission: Streitschrift wider die Kommission für Zukunftsfragen der Freistaaten Bayern und Sachsen" Berlin: Senatsverwaltung für Arbeit, Berufliche Bildung und Frauen, Arbeitsmarktpolitische Schriftenreihe Band 33, 1998. 
Streeck, Wolfgang. "Kontinuität und Wandel im deutschen System der industriellen Beziehungen: Offene Fragen" Arbeit, Vol. 10, No. 4, 2001, pp.

Sulk, Elmar. [Interview] public relations officer for the BDA, Berlin, July 23, 2002.

Tietmeyer, Hans. Die soziale marktwirtschaft erneuern. Cologne: Chancen für alle, 2001.

Thelen, Kathleen. "Why German Employers Cannot Bring themselves to Dismantle the German Model" Torben Iversen, Jonas Pontusson and David Soskice, Unions, Employers, and Central Banks Cambridge: Cambridge University Press, 2000, pp. 138-169.

Thelen, Kathleen and Christa van Wijnbergen, "The Paradox of Globalization: Turning the Tables on Labor and Capital in German Industrial Relations" Evanston: Northwestern University Institute for Policy Research Working Paper WP-00-9, 2000.

Thelen, Kathleen and Ikuo Kume. "The Effects of Globalization on Labor Revisited: Lessons from Germany and Japan" Politics \& Society Vol. 27, No. 4, December 1999, pp. 477-505.

Tilly, Chris and Charles Tilly (eds) Work Under Capitalism Boulder: Westview Press, 1998.

Trittin, Wolfgang. Telephone Interview. December 5, 2002.

Trittin, Wolfgang. Personal communication. November 14, 2002.

Tüselmann, Heinz and Arne Heise, "The German model of industrial relations at the crossroads: past, present and future" Industrial Relations Journal Vol 31, No. 3, pp. 162-176.

Voß, Günther and Hans J. Pongratz. "Der Arbeitskraftunternehmer" Kölner Zeitschrift für Soziologie und Sozialpsychologie Vol. 50, No. 1, 1998, pp. 131-158.

Wagner, Alexandra. Personal communication. January 22, 2003.

Womack, James P., Daniel T. Jones, and Daniel Roos, The Machine That Changed The World: The Story of Lean Production New York: HyperPerennial, 1991. 
Wood, Stewart. "Labor Market Regimes under Threat? Sources of Continuity in Germany, Britain, and Sweden" Paul Pierson (ed.) The New Politics of the Welfare State. Oxford: Oxford University Press, 2001, pp. 368-409.

Wood, Stewart. "Weakening Codetermination? Works Council Reform in West Germany in the 1980s" Berlin: Wissenschaftszentrum Berlin für Sozialforschung Discussion Paper FSI97-302, 1997. 